Special Issue on Design Science in Organizations

Research Article

\title{
A Design Research Business Model: A Framework Built with Brazilian Farmers
}

\author{
André Luiz Surdi Debastiani ${ }^{1}$ \\ Graziela Dias Alperstedt ${ }^{1}$ \\ Grazielli Faria Zimmer Santos ${ }^{1}$ \\ Graziele Ventura Koerich ${ }^{2}$ \\ ${ }^{1}$ Universidade do Estado de Santa Catarina, Florianópolis, SC, Brazil \\ ${ }^{2}$ Universidade Federal de Santa Catarina, Florianópolis, SC, Brazil
}

Received 13 March 2019. This paper was with the authors for two revisions. Accepted 6 November 2019. First published online 11 March 2020.

Guest editors: Aline Dresch, Daniel Pacheco Lacerda, Paulo Augusto Cauchick-Miguel, Joan van Aken, and Raymond Opdenakker

Editor-in-chief: Carlo Gabriel Porto Bellini

Editorial assistant: Luciane Kato Kiwara 


\begin{abstract}
This study aimed to propose a business model framework for Brazilian agriculture from an integrative perspective between theory and practice. To do so, Design Research was adopted from the triangulation of data, combining primary and secondary data collection, a systematic review of the literature on the business model and its main frameworks. Field research included the application of a questionnaire with 531 producers and an in-depth interview with another 30 to capture their insight into the factors that influence their business performance. The results of the study revealed that unlike other sectors, which have customers as the central point of the business value generation proposal, in commercial agriculture organizations occupy this place, as they are focused on the production of commodities. In view of this, the proposed artifact has financial viability as the central pillar of the agricultural business model, with production costs, product sales prices and agricultural productivity as its main components.
\end{abstract}

Keywords: design research; business model; Brazilian farmers; Brazilian agriculture. 


\section{Introduction}

The social and economic importance of Brazilian agriculture is indisputable. According to data from CEPEA-USP/CNA (Centro de Estudos Avançados em Economia Aplicada [CEPEA], n.d.), agriculture is responsible for about $24 \%$ of Brazilian GDP and an export revenue of US $\$ 85$ billion, or more than $45 \%$ of the total Brazilian exports. This performance has led the country to occupy a prominent position in the international market, becoming the leading net exporter of agricultural products worldwide. Brazil currently holds the title of the world's largest exporter of orange juice, sugar, coffee, soy, beef, and poultry, as well as the title of the world's largest producer of orange juice, sugar, and coffee (United States Department of Agriculture [USDA], 2017).

The dynamism of agriculture has a substantial impact on job creation. The Brazilian official records on employment (Ministério da Economia, 2016) showed that more than 5.9 million formal workers were employed in the sector in 2016, which represents $12.1 \%$ of formal jobs. Also, agriculture accounted for $9 \%$ of the total employment variation in the country between 2000 and 2015, and 20\% of this variation was in production activities within farms.

Brazilian farmers are directly responsible for sector success. Agricultural activity has been through a significant transformation in the past years, from an activity sometimes strongly related to a history of the farming family and tradition, to a sophisticated and competitive operation that demands more than just the will and perseverance of the producer. The ongoing changes are required to understand the current business model, including the business purpose and the value generated by farmers and their families. In addition, the transformations in the sector demand the ability to identify the business components and promote interactions among them to create a competitive advantage, which leads to greater professionalization.

Therefore, farmers who are not prepared to cope with the transformations in the sector tend to exchange the high risks of the activity for a fixed income provided by the lease of their land. The consequence is a process of consolidation in agriculture (which happens in many other sectors of the economy), and large business groups take advantage of the lack of competitiveness of farmers who do not face their activity as a business but as a lifestyle.

Most Brazilian farmers find it difficult to identify the components of their business and to measure its impact. Their choices are primarily based on intuition, tradition, and information passed on by local agents, and most often there is no business structure or long-term planning to guide the decision-making process.

Agricultural activity has undergone numerous transformations over the last century, driven by the evolution of science and technological intensification, which characterizes modern agriculture today, according to Buainain, Alves, Silveira and Navarro (2014).

Brazil experienced this period of intense modernization since the 1950s, also associated with the industrialization and urbanization of the country. This process, however, was uneven and heterogeneous, inevitable in view of the depth, scope and territorial scope of the socioeconomic

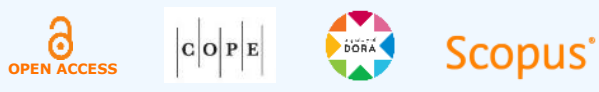


changes triggered in the Brazilian countryside (Buainain, Alves, Silveira, \& Navarro, 2014). The analysis of the income earned by the properties, with or without capital amortization, shows that the remuneration of labor is extremely low for most properties, putting into question economic viability.

In the modernization process, only one group of farmers was able to accumulate resources that were used to finance the deployment of new technologies and to pay off financial commitments (Alves, Contini, \& Hainzelin, 2005). Over the years, Brazilian agriculture has strengthened its dual nature: on the one hand, nearly 1 million producers rapidly absorbing new technologies to improve their competitiveness and, on the other, 4 million properties on the fringes of modernization, whose viability represents a considerable economic, political and social challenge for the country (Alves et al., 2005).

Against this backdrop, this work seeks to build, in partnership with farmers, and using Design Science Research, a business model applied to the medium-size Brazilian farmers. According to data from the IBGE Agricultural Census (Instituto Brasileiro de Geografia e Estatística [IBGE], 2006), there are 5.2 million agricultural establishments in Brazil, $78 \%$ of which have an area smaller than 50 hectares. These establishments, which together account for $13 \%$ of the total area, fall under family farming, which is now met by Federal Government programs that offer subsidized interest rates and differentiated conditions to boost production and keep these workers in the field, such as National Family Farming Program (Programa Nacional de Fortalecimento da Agricultura Familiar [PRONAF]). When one looks at agriculture, excluding family farming, one encounters commercial agriculture, where market laws predominate, and the government's presence through the Agricultural and Livestock Plan is limited. Considering establishments above 50 hectares, there are 862,700 agricultural establishments engaged in agriculture or livestock as a commercial activity. Using data from the IBGE Agricultural Census (IBGE, 2006), these establishments can be further divided into three categories: small producers, who plant up to 200 hectares (71\%), medium producers who plant between 200 hectares and 1,000 hectares (24\%), and large producers cultivating more than 1,000 hectares $(5 \%)$.

The research focused on Brazilian commercial agriculture, especially on soybean and corn production. This extract is chosen because it is the group where there is a greater opportunity to study the application and use of business models due to the great complexity in the management of these producers activities and the perception that it is possible to contribute to meeting the needs of producers regarding business management.

The theme of business models is recent and still little explored in agriculture, even though the literature review carried out by Tell et al. (2016) showed that the interest in the issue has grown in the last five years. The authors observe, however, that most of the studies on business models in the agri-food sector refer to cases describing the importance of the value chain and business models in the context of industry challenges as a whole. The theoretical approach adopted by the articles reviewed by Tell et al. (2016) in their attempt to provide a theoretical framework for the industry, is dispersed and rarely empirically applied, indicating the need for further research on specific problems within the sector. The studies started from different perspectives of analysis

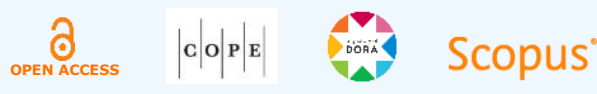


and, despite their contribution, they are not adequate to unveil the reality of Brazilian agriculture. With this work, it is expected to contribute to the development of abstract scientific knowledge (problem class) related to the implementation of the strategy in commercial agriculture, bringing together the organizational structure and the technology employed, by the development of a business model (artifact) that can be useful for organizational action (Lacerda, Dresch, Proença, $\&$ Antunes, 2013).

As for the other important component of this study, Design Research, the studies supported by this method are oriented to dealing with specific problems (such as the one presented here), looking for, at least, a satisfactory solution (Dresch, Lacerda, \& Antunes, 2015). However, the prescriptive nature of Design Research does not mean that there is a lack of methodological rigor and relevance (Brendel, Zapadka, \& Kolbe, 2018). On the contrary, these elements are crucial to validate the research as a piece that contributes to the expansion of the existing knowledge base (Dresch et al., 2015; Hevner, March, Park, \& Ram, 2004; Santos, Koerich, \& Alperstedt, 2018). Therefore, this work is committed to these principles in proposing a business model for Brazilian farmers, seeking to assist them in understanding the components that affect the business and improve management.

\section{Business Model}

The term business model first appeared in the academic literature in 1957. However, it was only around the year 2000 that it gained importance, together with the rise of the Internet and ecommerce companies (Osterwalder, Pigneur, \& Tucci, 2005; Zott \& Amit, 2009).

According to Magretta (2002), the use of the term business model became popular with the introduction of personal computers and spreadsheets for calculation, devices that allowed an analytical approach to the planning of each component of business regarding finances and statistics. The term helped to quantify and test each feature of the business and was perceived as an essential part of communicating the potential value of the investment to interested investors. Nowadays, connecting business model with spreadsheet is no longer accurate, and the application of business models is way beyond numbers alone (Mansfield \& Fourie, 2004).

Vodovoz (2015) argues that the first definition and classification of the business model was presented by Timmers (1998) who, based on the information technology point of view, stated that business model is an architecture for a product, service, and information flow. The author says that a business model includes the description of the actors related to the business and the roles they play, as well as the description of the potential benefits for each of these actors and the revenue streams.

There is still no consensus among scholars about the concept of a business model. The main authors did not agree on a single concept that defines it (Klang, Wallnofer, \& Hacklin, 2010; Morris, Schindehutte, \& Allen, 2005; Zott, Amir, \& Massa, 2011), but there is a convergence between the various definitions found in articles and books, which points to an understanding

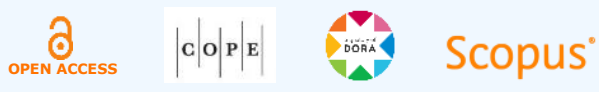


that a business model is directly related to the creation, delivery, and capture of value (Osterwalder \& Pigneur, 2009).

Vodovoz (2015) reveals different concepts and focus of analysis that have evolved. The most recent development, according to the author, describes a business model as a "broad business design tool for business creation and innovation, that covers the variety of organizational aspects" (p. 32).

For authors such as Chesbrough and Rosenbloom (2002), Osterwalder, Pigneur and Tucci (2005), and Osterwalder and Pigneur (2009), a business model includes the identification or coordination of the following elements: (a) value proposition, including how the value is generated; (b) customer segment, showing who will use or consume products or services; (c) customer relationship, focusing on how the business engage customers; (d) channels, or how clients are reached, including forms of raising awareness and providing information; (e) key activities, coordinating the activities needed to carry out the other operations of the business; ( $\mathrm{f}$ ) key resources or the critical assets required; (g) key partners, observing the actors that are critical in the process of delivering the value proposition; (h) cost structure and revenue streams, describing key costs and how the organization generates revenues.

The authors, concepts, and insights about business models adopted in this study are similar to those in Vodovoz (2015), which are represented by the works of Osterwalder and Pigneur (2010), Teece (2010), and Nielsen and Lund (2012). The essence of a business model is

in defining the manner by which the enterprise delivers value to customers, entices customers to pay for value, and converts those payments to profit. It thus reflects management's hypothesis about what customers want, how they want it, and how the enterprise can organize to best meet those needs, get paid for doing so, and make a profit (Teece, 2010, p. 172).

Nielsen and Lund (2012) state that "a business model describes the coherence in the strategic choices which facilitates the handling of the processes and relations which create value on both the operational, tactical, and strategic levels in the organization" (p. 15), and connects resources, processes, and service supply for obtaining value and profit in the long term. For Osterwalder and Pigneur (2010), "business model describes the rationale of how an organization creates, delivers, and captures value" (p. 14).

Osterwalder (2004) says that the business model's role is to explain how the strategy will be executed through the processes, and it can be considered a shortcut to reduce the gaps that exist between strategy, organizational structure, and technology. Therefore, the business model works to combine these organizational elements. Johnson, Christensen and Kagermann (2008) share a similar point of view. For them, the business model can be understood as the implementation of the strategy.

Seddon, Lewis, Freeman and Hanks (2004) consider the business model as an abstract representation of some aspect of a company's strategy. In a way, all companies have a business

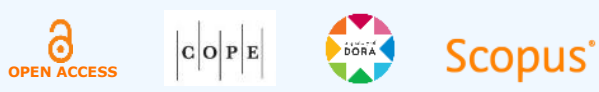


model and, even though companies operating in the same segment can present the same or very similar business models, the strategy behind their action plan is what influences their success.

Business model frameworks can be used to explore and plan how an organization will operate and compete, or to identify areas that need improvement. Among the different existing frameworks, the following stand out: (a) Resources, Competences, Organization, and Value Proposition (RCOV); (b) Customer-Integrated Business Model (CIBM); (c) the model by Johnson, Christensen and Kagermann; and (d) the Business Model Canvas.

The Business Model Canvas (BMC) is a framework that allows the visualization of structures, processes, and organizational systems for the implementation of business strategies. The structure provided covers the four main areas of a business: customers, offer, infrastructure, and financial viability, which, in turn, are formed by nine organizational dimensions: (a) customer segments; (b) customer relationships; (c) distribution channels; (d) value propositions; (e) key resources; (f) key activities; (g) key partnerships; (h) revenue streams; and (i) cost structure. This model has proven to be the most complete in the business model theory. It addresses in detail the relationship of all internal and external organizational components and shows how these elements relate to create and capture the value proposed by the organization (Vodovoz, 2015).

The BMC was developed from Osterwalder's first studies (2004), and initially called Business Model Ontology. The starting point of this ontology was the definition of four main areas to which a business model must respond, also called by the author the four pillars: product, customer interface, infrastructure management, and financial aspects. When defining these four pillars, Osterwalder (2004) had as reference the four perspectives of the Balanced Scorecard Model (BSC): Financial Perspective, Customer Perspective, Perspective of Internal Processes and Perspective of Learning and Growth.

Later, in order to develop a complete model, Osterwalder (2004) divided the four areas into nine blocks, based on the most cited elements of the business model as shown in the literature: organizational - Key resources and Key activities; market - Customer segments, Customer relationship, Channels and Key partners; financial - Revenue streams and Cost structure; and value (propositions, creation, delivery and capture).

In addition to the business model discussion, Resource Based View helps to understand the case of Brazilian commercial agriculture. Resource Based View (RBV) is a theory developed from the ideas of Penrose (1959), Wernerfelt (1984), Grant (1991), and Barney (1991) to help understand which factors influence the performance of organizations and how some organizations outperform others.

According to Carvalho, Prévot and Machado (2014), most of the agricultural products sales market is recognized as an approximate structure to the perfect competition market. In perfectly competitive markets, as in the neoclassical economic models, all firms would in the long run reach a situation of performance symmetry, and eventual differences would be merely transient phenomena, soon corrected by market mechanisms (Brito \& Vasconcellos, 2004).

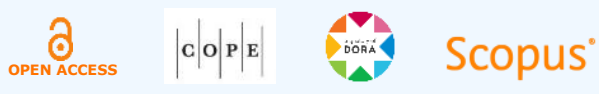


What can be observed in practice, however, is very different. In the current agricultural context there are marked differences in profitability between farms, even between those located in the same region and producing the same products. This heterogeneity can be explained by analyzing the resources and internal capacities of each property, which makes RBV a valuable tool for analyzing the factors that generate competitive advantage for agriculture.

In the context of RBV, the internal characteristics of an organization are primarily responsible for superior performance. The central proposition of this theory is that the source of competitive advantage lies primarily in the resources and capabilities developed and controlled by firms, and only secondarily in the structure of the industries in which they are positioned (Barney, 1991).

\section{Proposal Using Design Research}

The objective of this work is to propose a business model for Brazilian farmers described by themselves from their key experiences, helping them to understand the components that affect their business and improve management. The research was conducted by collaboration between researchers and farmers in building a business model proposition. Therefore, data were collected based on the reality of the farmers, through direct and interactive contact with them. In addition to the qualitative information collected from the interaction, the study used quantitative data obtained through questionnaires, which allowed identification of critical success factors of the agricultural businesses surveyed. The combined use of qualitative and quantitative data, forming a mixed method, was useful to provide a better understanding of the problem researched (Creswell, 2010) and grounding to support the proposed business model.

In this study, the first stage of the Design Research cycle identified the problem - described in the introduction of this article - through interacting with a group of farmers. In short, there is a lack of tools to help farmers develop a more structured view about their businesses, promoting competitiveness in the face of all the transformations affecting the agriculture industry.

After understanding the problem, the study focused on the diagnosis, analyzing data collected through questionnaires and interviews. After that, a systematic literature review was carried out to verify the existence of business models applied to agriculture (the business models found were presented in the previous section of this article).

Based on the first and the second stages, we produced a synthesis and carried out the next stage of the research, proposing a business model for Brazilian farmers. The last stage of the design cycle in the study presented in this article was represented by feedback from the farmers, followed by the reflections and lessons learned, culminating in the communication of the research results in the form of this article and a report back to the farmers. Due to the time required to complete the proposal it was not possible to evaluate its implementation.

As to data collection, it is important to mention that interviews and questionnaires with farmers were conducted in a way that facilitated the interaction between the different actors involved in the business. The steps regarding the stage of data collection are the following: the interview

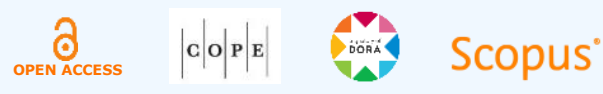


phase allowed a significant interaction between the researchers and the subjects. There were three field research sections, and 30 interviews were conducted. The first occurred January 23-28, 2017, in the states of Paraná and Mato Grosso do Sul. The second was February 19-23, 2017, in the state of Mato Grosso. Finally, the third was June 5-9, 2017, again in the states of Mato Grosso do Sul and Paraná. The interviewees were selected based on accessibility during a technical visit to collect data about the harvest, carried out by the consulting company Agroconsult in the main regions of soy and corn production in Brazil. Each interview lasted about 30 minutes, and the answers were recorded in field diaries. The interviews were semi-structured and informal, to allow for greater interaction between the researcher and the respondents. During the interview, several topics were explored concerning the current context of agriculture, to capture the farmer's view of the factors that influence the performance of their business.

The analysis of the interviews was conducted in a process described by Creswell (2010), involving a continuous reflection on the data, allowing the formulation of analytical questions while making notes throughout the data collect. The process of data interpretation coincided with the data collection and writing of the report, allowing the construction of the business model from categories identified from the interviewees' speech.

The questionnaires (Appendix) were applied to farmers to identify the importance of several factors in creating competitive advantage in agriculture. The instrument had 31 questions, and the respondent indicated the degree of impact of each factor, with 1 for very low and 5 for very high. The theoretical reference used to define the categories of analysis was the resource-based view (RBV). According to Grant (1991), resources that generate competitive advantage for the business can be classified into six categories: financial resources, physical resources, human resources, technological resources, reputation, and organizational resources. For each of these categories, different factors were selected based on the analysis of previous studies about the use of RBV in agriculture, such as the work by Carvalho et al. (2014). About 1,200 farmers received the questionnaires between April 3-27, 2017 and 531 answered the questions. After an analysis of consistency in the questionnaires received from farmers, the sample was reduced to 388 questionnaires. Together the farmers participating in the research represent a planting area of more than 500 thousand hectares, about $1.5 \%$ of the area of soybeans cultivated in the 2016/17 harvest, according to Companhia Nacional de Abastecimento (CONAB, 2017). Among the respondents, 63\% come from the South Region of Brazil, 19\% from the Southeast Region, 12\% from the Center-West Region, 5\% from the North Region and 1\% from the Northeast Region. After collecting the data from the questionnaires, the results were analyzed using descriptive statistics.

The database and documentary research was conducted in three parts. First, articles were selected in the Scopus, Ebsco, Capes and Google Scholar databases, using and combining constructs (in Portuguese and English) that refer to the strategic management of rural properties such as: farm management, gestão de propriedades agrícolas [farm management], modelos de gestão [management models], planejamento [planning], agricultura [agriculture], agriculture, agrícola [agricultural], rural, fazendas [farms], farm, agronegócio [agribusiness], and agribusiness. The search resulted in a total of 107 articles that were used as reference to understand how the

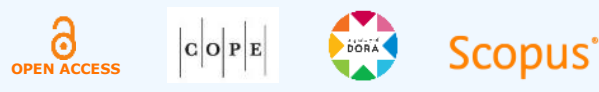


academic literature addresses the issues related to the strategic management of farms both in Brazil and internationally. Through the relevant academic production, it was possible to observe, even in an exploratory phase of the research, that the understanding and use of management models by farmers in their business, are still incipient or used for control. In general, we noticed during the conversations with farmers and consultants that, although the farmer knows their property very well and has a high level of excellence in the execution of agricultural activities, they do not have a broader view about the context of their business.

The second part of the documentary analysis aimed at identifying the main theoretical references on business models and their application in agriculture. By using and combining constructs (in Portuguese and English) such as Business Model, Modelo de Negócio [Business Model], RBV, Resource-Based View, VBR, Visão Baseada em Recursos [Resource-Based View], agricultura [agriculture], agriculture, agrícola [agricultural], rural [rural], fazendas [farms], farm, agronegócio [agribusiness], and agribusiness, the search identified 162 articles on the topic. After reading, all material was cataloged in a specific database and classified according to its relevance for this research. In this part of the research, as well as understanding the theoretical constructs about these subjects, it was possible to verify the inexistence of works that deal with business model and RBV together, applied to the case of farmers.

In the third part, secondary data on the sector were collected in public databases, such as the Brazilian Institute of Geography and Statistics (IBGE), the public National Food Supply Company (CONAB), and the Brazilian Agricultural Research Corporation (Empresa Brasileira de Pesquisa Agropecuária [EMBRAPA]), which helped in the contextualization regarding the importance of the sector. Also, studies carried out by institutions related to agribusinesses such as Agroconsult and Aprosoja were used. They were of great importance to understand and interpret the results achieved in this research.

\section{The Product: A Business Model for Brazilian Farmers}

There are numerous works in the literature on the concepts behind the construction of a business model, its importance in helping carry out business strategy and the application in different sectors of the economy. However, there is little reference to the use of a business model in the agriculture industry.

This gap is not due to the inapplicability of the methodology or the inexistence of a need for the sector to use it. After the green revolution in the 1950s, agriculture underwent major transformations that made it increasingly complex, in which the profitability of the business gradually depended less on the soil quality and the climate, and much more on the internal management of production factors. The interviews showed that farmers are aware that business success depends on a set of variables that are increasingly complex and difficult to manage. At the same time, however, few measures were observed to identify and understand how each of these variables relates to and influence business outcomes. The farmer has little control over all production factors, and one of the main reasons is not knowing them, or not understanding how they relate and influence the business.

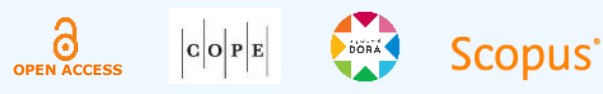


Thus, a business model for farmers aims to meet their need to understand the business logic, identifying how resources, processes, and suppliers relate and how they generate value for clients and the business.

The proposed framework considers the actors' perspective and is based on the Osterwalder and Pigneur (2010) business model canvas, which was adapted according to the reality of the agriculture industry.

As observed in Figure 1, the core of the proposed model is a business's financial viability, since the industry is based on commodities, suggesting a value proposition for the business. There are three main elements in the company's profit generation: production cost, productivity, and price of products sold. On the left is the infrastructure needed to generate value for the business, composed of key resources, key activities, and partnerships. On the right is the market component, composed of interactions with society, government, and their supply and demand conditions. Finally, the figure presents the commercialized products, which reflect the value proposition for the client, and are described in sequence.

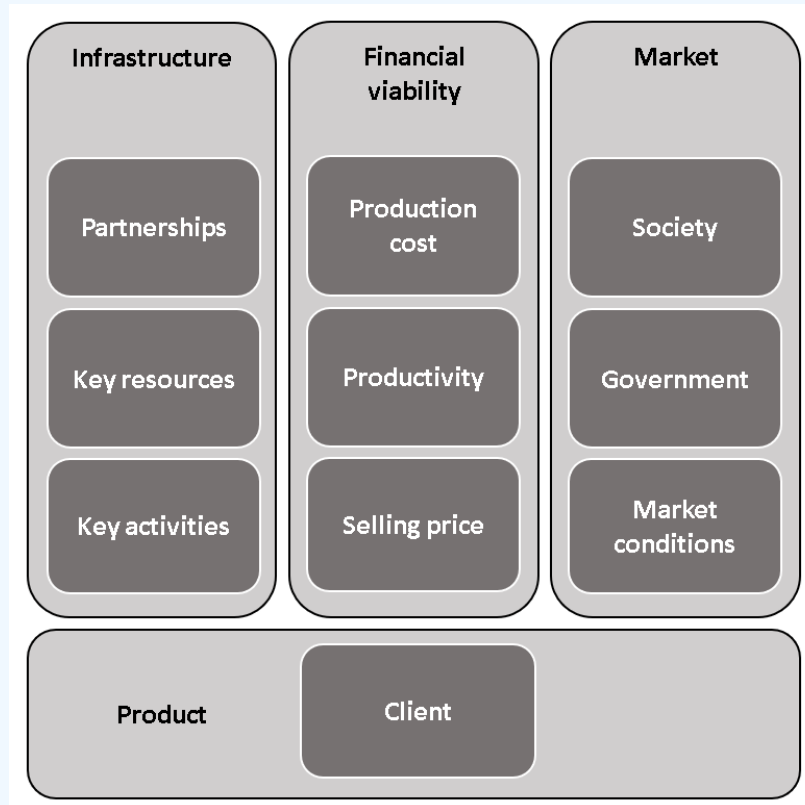

Figure1. Framework of the business model for medium-sized Brazilian farmers Source: Elaborated by the authors.

\section{Production costs}

Production costs, selling prices, and productivity are the three main components that determine the degree of the business return. The cost of production can be considered the component on which the farmer exercises greater control since the price of a commodity is defined by the stock exchanges and the main variable influencing productivity is the climate. 
The component production costs, proposed as one of the central parts of the business model for farmers, concerns not only the monetary value spent or invested over a harvest but also comprehends a set of factors related both to cost management and the strategy to purchase agricultural supplies. Some of these factors are: (a) measurement and allocation of production costs; (b) strategy to balance the costs and the technological devices and systems adopted; (c) strategy to purchase supplies; (d) financial leverage strategy; (e) management of administrative costs; (f) strategy of setting costs related to production, among others.

When asked about the way production costs were calculated, the majority of the farmers affirmed considering the supplies (seeds, pesticides, fertilizers, labor, fuel) and a few other expenses made throughout the harvest. Generally measured in soybean bags per hectare, this form of calculation reveals a limited view of all production costs, which should also include items such as depreciation of machinery and tools, financial costs arising from capital leverage, transportation and storage costs, administrative costs, costs of third-party services. The farmers' responses during the interviews illustrate this issue: "my soybeans production costs in the last harvest were 29 bags per hectare", "I am well aware of the production costs of this harvest, but I do not have record of the past harvests." The legal obligation to calculate the results of individual rural producer activities for tax purposes is through bookkeeping of the cash book, as regulated by Decree No. 9,580 of November 22, 2018 (Regulamento do Imposto de Renda (Decreto no. 9.580, 2018)). It records all revenues, costing expenses, investments and other values that interact with the activity. This, by itself, is not configured as a management tool, which makes it even more difficult to correctly calculate production costs within a rural property.

Another major challenge reported during the interviews concerns the difficulty of balancing the technology adopted with the real needs and context. It was not by chance that the variable crop planning presented the highest score among all items of the questionnaire, which reveals its importance in the activity. For example, there is no point in investing in higher technology seeds in order to obtain higher yields, if the soil does not have a suitable level of fertility.

\section{Selling price}

As previously mentioned, the price of a commodity is defined by the context of global supply and demand of the product and its sale is carried out on stock exchanges worldwide. Although the farmer has little room to influence the product's price, there are commercialization strategies that may result in higher profitability.

The interviews showed that few farmers efficiently manage a product's commercialization. Usually, the farmer chooses to harvest before looking for alternatives to sell the product, and therefore is susceptible to price volatility. Because it is a commodity, priced in dollars on the international market, countless variables can influence the price throughout a crop. At the same time that a crop failure in the United States can raise prices in the international market, the currency valorization of the Brazilian Real $(\mathrm{R} \$$ ) may lead to a fall in the price of the product for Brazilian farmers. Although there are climate forecasting models worldwide and countless

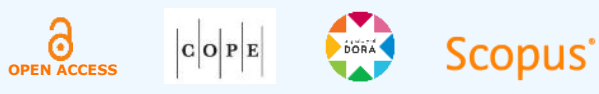


economists analyzing the currency market daily, there is enormous uncertainty about the future behavior of these variables.

Establishing a price-fixing strategy throughout the harvest, not only to achieve higher prices but also to ensure good profitability for the activity, is an essential component of the business model applied to farms and for generating value for the farmer.

\section{Productivity}

In agriculture, the term productivity refers to the quantity produced per unit area, usually defined in $\mathrm{kg}$ per hectare or bags per hectare. This measure differs somewhat from the term used in the economy to measure country productivity, which takes into account how much each worker produces in monetary terms throughout the year. Field productivity applied in agriculture does not measure all production factors of a farm. The use of this measurement sometimes leads to a misinterpretation of the production efficiency since high productivity may hide a high cost of production, which does not necessarily show that one property is more efficient than another.

In any case, field productivity is an important indicator in determining the profitability of production and is a measurement well used by farmers. During the interviews, it was clear the farmers' obsession in achieving above average productivity in their region. In the interviewees' words, "the average soybean productivity in the last crop was 61 bags per hectare, which was the best result since I started planting on this farm", "for the next year my productivity goal will be even greater", "what generates competitive advantage in my business? High productivity."

High productivity is not just about investing more in terms of supplies and machinery. There are several factors for a farm to obtain superior results. The first and perhaps the most important is the climate. Although farmers cannot influence it, they can develop the capacity to adapt and manage the production to maximize results or avoid more significant losses. This capacity can be observed in crop planning, at the beginning of the planting process, observing the raining season, selecting the genetic material according to its cycle, planting season, and soil moisture condition, as well as scheduling the planting time to avoid all of the crop being at the same level of climatic risk. Also, the farmer must observe the beginning of the field operations such as spraying and top-dressing fertilization, and the beginning of the harvest that is carried out during a critical period of rains.

In addition to the variable climate, the balance between technology and management according to the reality of each farm stands out. This item has already been explored within the component production costs, and strongly reflects the need for the farmer to know the reality of the farm to maximize productivity. The technical knowledge about the farming activity was pointed out in the questionnaire as the second most important item that influences business performance. In agriculture, it is often said that there are no universal practices when it comes to supplies and production management. Each context demands adaptation to achieve maximum productivity. Even within the same farm, there are big differences in terms of soil quality, altitude and climate that require different management.

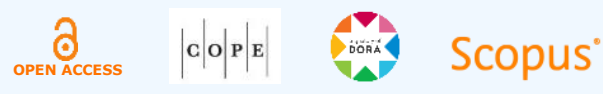


Despite this variation, there were many reports in the interviews of farmers who adopt the same technology package for the entire farm, regardless of the characteristics of each field. It was possible to verify during the interviews that knowledge of production history and the characteristics of each farmyard is still low. Some have reported knowing their farm very well since they carry out the activity in the same area for a long time and remember what happened in each field. This perception, however, is intuitive and lacks more control and science to justify the reasons leading to better results. In the interviewee's words, "I know my farm well, for I was raised from childhood on this land", "we know more or less which are the best areas."

\section{Key resources}

The key resources component was analyzed in the resource-based view (RBV) business model. It lists six types of resources that generate competitive advantage within an organization: financial resources, physical resources, human resources, technological resources, reputation, and organizational resources (Grant, 1991).

Analysis of the questionnaire revealed three groups of resources, separated based on their importance. The first is the human resources and reputation, the second the organizational and technological resources, and finally the physical and financial resources. The analysis of the median observed in the results, however, shows that the respondents attributed the same degree of importance to all resources. Because of the space limit for this article, the data from the questionnaires are not shown, but they can be obtained by contacting the authors.

\section{Key activities}

As described by Osterwalder and Pigneur (2010), the key activities component represents the most important actions a company must take to operate successfully. In the same way as the key resources, key activities are necessary to achieve the value proposition of the business model.

In the analysis of the interviews, the key activities in agriculture were divided into four categories: (a) operational activities; (b) business activities; (c) administrative/financial activities; and (d) management activities.

The operational activities are the ones related to the planning and execution of all activities carried out on the farm. Commercial activities are the purchasing of supplies for production as well as the commercialization of the products (soybean and corn) produced. Both are purposely within the same set of activities since they are interdependent. As discussed earlier, it is positive in the business model for farmers that production costs are tied to the commercialization of the product so that there is no mismatch over time between costs and revenues.

The administrative and financial activities refer to all other mandatory actions that are common to other industries and necessary for the correct business functioning. Among these activities are performance evaluation; accounting, fiscal, and labor obligations; establishing and following

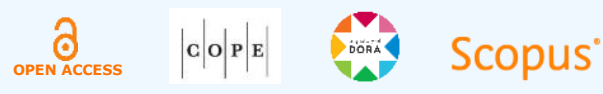


human resource policies; internal communication; obtaining funding; making payments and collections; and others. Although most are bureaucratic activities, they play an essential role in fulfilling the company's value proposition. The variable company's financial management is within the set of variables that presented median and mode of value 5 in the questionnaire applied.

Because the agricultural activity is mostly carried out by the individual, often administrative and financial activities are poorly structured within a farm. In the interviewee's words, "our farm generates around R $\$ 3$ million per year and my wife, son and myself alone run the business."

Managerial activities are most often under the direct responsibility of the farmer. They have to plan and manage all farm resources (physical, human, and organizational), seeking the maximum synergy between the different activities, and being prepared to solve the problems inherent to daily activity.

\section{Partnerships}

Another component of the business model that is part of the infrastructure area is partnerships, which deal with the network of suppliers and partners that put the business model to work. Although often not well explored, partnerships are crucial for generating value for the business. They may be of great use in finding better opportunities to purchase supplies, obtain better funding conditions, design storage strategies, make improvements for the industry as a whole, introduce new technologies to work the land, among others benefits. A good relationship with clients and suppliers was listed in the questionnaire as the fourth most important variable for the performance in the activity. One of the main forms of building partnerships is the cooperative. This type of organization is widespread in Southern Brazil and provides benefits to the associated farmers, such as funding and technical and commercial support. Other partners worth mentioning are service and technology providers.

\section{Market analysis}

In the market area of the framework, the analysis of supply and demand is a key element in the business model for farmers. As discussed before, because it is a commodity market, with prices fixed on the stock exchange, farmers have little influence on the final price, but there are ways to reduce exposure to market oscillations. The first step in this direction is to understand what is happening in the market, and being able to hold a good position when negotiating.

According to data from the US Department of Agriculture (USDA, 2017), today, Brazil is the largest soybean exporter in the world and the second largest producer, behind only the US. The largest consumer in this market is China, with 64\% of world imports. Over the past 20 years, world soybean production has grown at a rate of $5.0 \%$ per year, and the consumption grew $4.6 \%$ per year over the same period, observing a tendency of continuous growth of income and population in Asian countries. Against this backdrop, Brazil became a priority supplier of

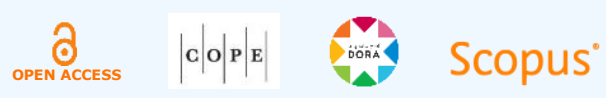


soybeans to Asia, which allowed domestic production to grow at a rate of $7.5 \%$ per year over the past 20 years. Currently, the market is oversupplied. A series of good harvests in the main producing countries (USA, Brazil, and Argentina) caused the stocks to reach record levels in the 2016/17 harvest, directly affecting the price.

This scenario of oversupply has caused soybean prices on the Chicago stock exchange to fall $18 \%$ from US\$11.0 per bushel in June 2016 to US\$9.0 per bushel in June 2017. In the domestic market, the fall was more pronounced due to the devaluation of the Brazilian currency. The prices of soybean in the port of Paranaguá, as measured by CEPEA (n.d.), fell by $27 \%$, from R $\$ 95.2$ per bag in June 2016 to $\mathrm{R} \$ 68.5$ per bag in June 2017. In addition to these two variables, others that directly affect the pricing of the product in the domestic market can be mentioned, such as contractual shares paid to ports, port fees, freight behavior over the last year, the positioning of funds in the commodities market, among others.

\section{Society}

Within the area of market in the framework, society can be understood as another link of great importance in the elaboration of the business model for Brazilian farmers. Increasingly, farming production has been influenced by demands that come from society, whether environmental or social. Many of them are not exactly legal demands and helped to design a new pattern of agricultural behavior. An example was the Soy Moratorium, which was an agreement of organizations representing farmers committing not to commercialize, purchase, or fund grains produced in areas of illegal deforestation in the Amazon biome, after July 2008. After 11 years of operation, the initiative helped reduce deforestation in the Amazon and has become an example of how industry, governments, consumers, and NGOs can work together to find solutions to environmental problems through the market.

Many farmers already connect farming with the concept of sustainability, since they believe that the consolidation of agriculture will only take place when all environmental and social aspects are adequately considered. During the interviews, the farmers demonstrated that the concern to adapt their reality to all legal and also non-legal requirements, was strongly present in their lives, to the point that this issue is included in the values guiding their work on the farms. "Maintaining a good image with the other actors in the production chain" and "transparency regarding environmental and social issues" were items addressed in the questionnaires as variables of great importance and obtained high scores in terms of influence in the business performance.

\section{Government}

The government is another component of the proposed business model since the industry is highly regulated and subject to great intervention. The Plano Safra, a Brazilian federal government plan to support agriculture, is perhaps one of the most relevant examples of how the sector still depends on the government, including financially. Announced in June 2017, the Plano Safra 2017/18 estimates the allocation of $\mathrm{R} \$ 190.25$ billion to Brazilian agriculture. The

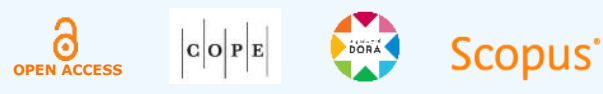


resources are offered at controlled rates to fund the agriculture industry, encourage investments, and assist in product commercialization.

In addition to the Plano Safra, it is important to point out the industry's dependency on investments in logistics infrastructure, particularly from the Federal Government. Unlike in the USA, where highways are used to transport $5 \%$ of the production, $60 \%$ of the production in Brazil is transported by trucks through federal and state highways to export ports, which are often more than 1,200 miles away from production regions (EMBRAPA, 2015).

Another component that shows the government's intervention in the sector is the provisions of Law 12651 establishing the Forest Code (Lei n. 12.651, 2012). The bill passed in the Brazilian Congress five years ago, and its provisions have not yet been implemented, which represents legal insecurity for the business. The recent intervention of the government, through a new interpretation of Law 5709 by the Office of the Attorney General (Lei n. 5.709, 1971), which deals with the acquisition of land by foreigners, equates Brazilian companies whose majority of share capital is controlled by foreigners and foreign companies. Also, there is a massive and complex tax burden that reduces the competitiveness of Brazilian agriculture. These and many other ways the government helps and disrupts the sector were reported by the interviewees. In their words, "if the government did not get in the way it would be great", "there is a lot of legal uncertainty in our industry", "our roads are getting worse", "today more than $60 \%$ of the price of corn is destined to cover the high transportation costs."

\section{Clients}

Unlike other sectors of the economy, where they have a prominent role in the organization's business model, in agriculture, the clients (represented by trading companies, grain traders, and cooperatives) who buy the product directly from the farmer are not the main link in business value generation. Regardless, the clients are present in the business model for farmers, and their importance cannot be ruled out.

The difference between client and consumer must be emphasized. The client, as already mentioned, represents the direct link with the farmer and the consumer, which is the participant at the end of the chain, and can be represented by the person that buys a breast of chicken in the supermarket. When considering that the chicken feeds on food that is about $30 \%$ soybeans, it is fair to recognize that the person buying the meat is participating in the soybean chain. This differentiation is important to illustrate the business relationship between farmers and clients. It is clear that the farmer has to be aware of consumer market demands (which was already explored in this article when describing the Society component).

Until a few years ago, soybean buyers were rare, restricted to about one or two per region. They had great negotiation power since they were the only selling option for the farmers. In recent years the operation of international trading companies in the Brazilian market has intensified, increasing competition among soybean buyers. This situation has put farmers in a privileged situation, since they can choose to whom they sell their product, according to the conditions

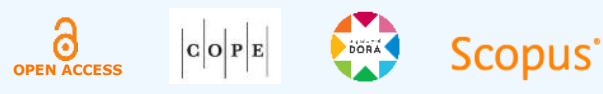


offered. The relationship between soybean farmers and buyers (trading companies) was presented in the interview as cold and merely commercial. In the interviewees' words, "I sell soybeans to whom pays more", "when I need to sell soy, I call two or three trading companies and decide by best offer", "I do all my selling through brokers. They are in charge of researching who is paying more."

\section{Theoretical and practical contributions}

Agribusiness Management is a topic that has been studied for a long time, especially in countries with a strong agricultural culture such as the United States and Australia. The works of Olson (2004) and McCown, Brennan and Parton (2006) are references of major studies on the subject. In Brazil, the theme has already been explored by several authors, such as Nantes (1997) and Nantes and Scarpelli (2001). Most studies, however, take a more sectoral approach and explore agribusiness management from a production chain perspective. Studies focused on the management of rural properties are rarer in Brazil, as is the case of the studies by Lourenzani, Souza and Bankuti (2003).

Similarly, the theme Business Models is recent and still little explored in agriculture. Research on business models in agriculture has grown over the past five years, as shown by the recently structured literature review by Tell et al. (2016). However, as noted by the authors' research, most studies related to business models in the agri-food sector concern case studies that aim to describe the importance of the value chain and business models in the context of the challenges they face. The theoretical approach of the articles to develop a framework for the sector is dispersed and little applied, needing more research in this specific area.

In their research on business model and performance indicators, Saunders, Kaye-Blake, Hayes, and Shadbolt (2007) tested several management tools in order to identify which one best fits the reality of agriculture. Vorley, Lundy and MacGregor (2009) studied the business models considered as inclusive for small producers. Poláková, Koláčková and Tichá (2015) tested three business models proposed in the Czech literature for agriculture. Björklund and Ulvenblad (2016) studied the barriers and challenges encountered by producers in 6 agricultural business models in Sweden. Pölling, Mergenthaler and Lorleberg (2016) made use of business models as a tool for geo-statistical analysis of urban agriculture patterns in the Ruhr metropolitan region of Germany. Long, Blok and Poldner (2017) identified critical issues in developing business models for technological innovations in smart climate solutions for agriculture. Antonaras and Kostopoulos (2017), in their studies, proposed a business model framework for agriculture as a way to promote economic growth in Europe and to combat unemployment and poverty in rural areas. All these studies came from different perspectives of analysis and, despite their contribution to their studied context, are not pertinent to the reality of Brazilian agriculture.

The reason why the authors proposes the research presented here is to believe that it is possible to elaborate a business model for Brazilian commercial agriculture that serves as a reference to help producers better understand the entire context of components that influence their business and better manage their activity. In addition to contributing to the development of Brazilian

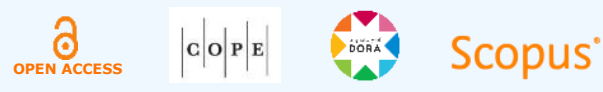


agriculture, it helps academic and management professionals to better understand the reality and demands of the country's agricultural producers.

The results of the study regarding value generation in the agricultural industry pointed in the opposite direction of most of the business model frameworks, such as the Osterwalder and Pigneuer (2010) Canvas model. While the central dimension of the value generation in the business model canvas is the customer, in commercial agriculture (which aims to produce commodities) the value generation of the business model is directed at the business itself, since there is no differentiation in the product or service provided. In this case, the profitability of the activity is the factor generating competitive advantage, and it is, therefore, the central point of the business model. This comprehension was of great importance to identify the components of the business model for farmers, as well as to understand how these components interact to generate value for the business.

The few differences in quality between one product and another, resulting for example from the presence of product impurities or moisture above the standards, are corrected by reference tables which may confer a bonus or penalty on the product price. This, however, does not constitute a differential in the sale of the product. The soybean produced in the state of Mato Grosso or the state of Rio Grande do Sul, or even in the United States, is the same. The client, here characterized by the trading companies who export the product, and the consumer industries also do not differentiate the product. This is so true that it is not the customer who chooses from whom he/she wants to buy the product, but the producer who chooses to whom he/she will sell his/her product based on the commercial conditions offered.

From this perspective, it can be concluded that the value proposition in developing the business model of a typical Brazilian soybean and corn farm is not customer-based. This perception is confirmed by the interviewed producers who recognize the importance of maintaining a good relationship with their customers, but do not consider it a determining factor for the success of their business. This is unlike other markets, where customer choice is based on a perception of value creation that the product or service offers. Here, the value generated for the customer and the price paid for the product are the same, regardless of the region where it was produced, the resources used, the sales channel, or the relationship created between the parties.

Of course, there are situations that go beyond this logic, but they are specific cases that must be dealt with separately. Examples include white hilo soybean production for human consumption, conventional or transgenic gene-free soybean production, or organic production itself. In these situations, the product has a differential that generates greater value for the customer and elevates prices. These situations represent niche markets nicely. If more producers decided to join conventional soy production, for example, the price differential paid today would cease to exist or would be greatly reduced, as there would not be enough demand for this product. Another situation that goes beyond this logic is the compliance with the legal and socio-environmental requirements. To meet the requirements of the end consumer market, many buyers require proof from producers that all legal, environmental and social compliances are being met in their production process. This can be seen in some excerpts from the interviews: "having a good

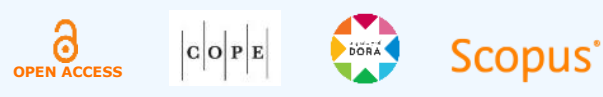


relationship with trading companies and cooperatives is important ...", " there is no large price differential paid for soybeans by the trading companies of the region", I use brokers to sell my product, I don't sell directly to the trading companies", "I try to deliver my product to more than one trading company ...", or "I prefer the trading company that is paying the best."

The results presented ten main components of the business model for farmers, which were then grouped into four areas for the construction of the proposed framework. The components are the production costs, productivity, and selling price, which correspond to the main elements in the company's profit generation and are in the area of financial viability. Key resources, key activities, and partnerships are in the area of infrastructure. The interactions with society, government and the market conditions regarding supply and demand are in the area of market, and, finally, the client, in the area of product.

\section{Conclusion}

The proposition of building a framework of a business model for Brazilian farmers was based on the lack of mechanisms to help farmers to have a more structured view of their business, to be more competitive in the market and to remain competitive in the face of all the transformations for which agribusiness is going through.

The interviews were limited to farmers in the Brazilian states of Paraná, Mato Grosso do Sul, and Mato Grosso. The questionnaires, however, allowed contact with farmers from other states such as Rio Grande do Sul, Santa Catarina, Minas Gerais, Goiás, Tocantins, and Bahia. Together these nine states account for $91 \%$ of soybean production and $88 \%$ of Brazilian corn production, which reflects the scope and relevance of the results obtained in the research.

The framework was elaborated by grouping the business components in a way that would best reveal their interactions and importance regarding value generation for the business. In the proposed framework, financial viability is central and represents the business value generation. The area of infrastructure is positioned at the left side and shows how the business outcomes are delivered. On the right side is the area of market, which represents the external environment. At the bottom of the framework is the area of product, which is the value proposition for the client.

Framework design took into account the cultural context of Brazilian farming production, where the activity is often mixed with the lifestyle of the rural population. Thus, the business model framework proposed could not be too technical or theoretical or require a high level of prior understanding of business models and strategic management to be adopted. The simplicity of the proposed framework meets these needs, since it enables the farmer to visualize clearly and directly how the business works, what components influence the performance, how this influence occurs and, above all, how and for whom the business generates value.

The next step to consolidate the proposed model is to implement the framework and collect the farmers' feedback. This part of the research has not yet been carried out due to time and resource constraints, but it is necessary to close the Design Research cycle. However, the results obtained

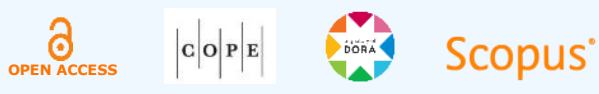


at this point have the potential to influence the development of new academic studies on the subject by proposing a more applied perspective, and also to assist managers, consultants and, above all, the farmers in building a strategic plan that takes into account the proposed framework and its components.

This research, therefore, fulfilled the intention to use the method of Design Science Research and managed to produce two main outcomes. First, the product, with its importance based on data collected and prepared, which will be consolidated in a future stage of testing. Second, the development of a theory, based on the generalization of the knowledge obtained throughout the process of constructing the product to a class of problems (Gregor, 2006; Gregor \& Hevner, 2013; Kuechler \& Vaishnavi, 2012), which, in this specific case, applies to the Brazilian mediumsize farmers.

Based on this, it is important to highlight the research limitations related to the context of application of the proposed business model. In this sense, the model does not apply to other areas of agriculture, such as food production from family, organic and agricultural agriculture, which do not market their products in the same format as those presented in this research. Therefore, future research may act on the model that encompasses all areas of agriculture or just other specific areas.

\section{Acknowledgments}

The authors are grateful to the Research and Innovation Support Foundation of Santa Catarina (FAPESC) and the Santa Catarina State University (UDESC) for the financial support to this research.

\section{References}

Alves, E., Contini, E., \& Hainzelin, E. (2005). Transformações da agricultura brasileira e pesquisa agropecuária. Cadernos de Ciência E $\quad$ Tecnologia, 22(1), 37-51. Retrieved from https://seer.sct.embrapa.br/index.php/cct/article/view/8686/4872

Antonaras, A., \& Kostopoulos, A. (2017). Stakeholder agriculture: Innovation from farm to store. In T. Tarnanidis, M. Vlachopoulou, \& J. Papathanasiou (Eds.), Driving agribusiness with technology innovations (Chapter 8, pp. 125 147). Hershey, PA: IGI Global.

Barney, J. B. (1991). Firm resources and sustained competitive advantage. Journal of Management, 17(1), 99-120. https://doi.org/10.1177/014920639101700108

Björklund, J. C., \& Ulvenblad, P. (2016). Sustainable business models in Swedish agri-food production - Challenges and barriers. $\quad$ Retrieved from https://www.researchgate.net/publication/309858887_Sustainable_Business_Models_in_Swedish_Agrifood_Production_-_Challenges_and_Barriers

Brendel, A. B., Zapadka, P., \& Kolbe, L. (2018). Design science research in Green IS - Analyzing the past to guide future research. Proceedings of the European Conference on Information Systems, Portsmouth, Hampshire, England.

Brito, L. A. L. B., \& Vasconcellos, F. C. (2004). Performance of Brazilian companies: Year effects, line of business and individual firms. Brazilian Administration Review, 1(1), 1-15. https://doi.org/10.1590/S1807. 76922004000100002

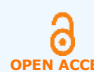

Scopus 
Buainain, A. M., Alves, E., Silveira, J. M. da, \& Navarro, Z. (2014). O mundo rural do Brasil no século 21: A formação de um novo padrão agrário e agrícola. Brasília, DF: Embrapa.

Carvalho, D. M., Prévot, F., \& Machado, J. A. D. (2014). O uso da teoria da visão baseada em recursos em propriedades rurais: Uma revisão sistemática da literatura. Revista de Administração, 49(3), 506-518. https://doi.org/10.5700/rausp1164

Centro de Estudos Avançados em Economia Aplicada (n.d.). PIB do agronegócio brasileiro. Retrieved September 13, 2017, from http://cepea.esalq.usp.br/pib/

Chesbrough, H., \& Rosenbloom, R. S. (2002). The role of the business model in capturing value from innovation: evidence from Xerox Corporation's technology spin-off companies. Industrial and Corporate Change, 11(3), 529. 555. https://doi.org/10.1093/icc/11.3.529

Companhia Nacional de Abastecimento. (2017). Levantamento de safra. Retrieved June 13, 2017, from https://www.conab.gov.br/info-agro/safras/graos/boletim-da-safra-de-graos?start=30

Creswell, J. W. (2010). Projeto de pesquisa: Método qualitativo, quantitativo e misto. Porto Alegre, Brazil: Artmed.

Decreto $n^{\circ}$ 9.580, de 22 de novembro de 2018. (2018). Regulamenta a tributação, a fiscalização, a arrecadação e a administração do Imposto sobre a Renda e Proventos de Qualquer Natureza. Retrieved from http://www.planalto.gov.br/ccivil_03/_ato2015-2018/2018/decreto/D9580.htm

Dresch, A., Lacerda, D. P., \& Antunes, J. A., Junior. (2015). Design science research: Método de pesquisa para avanço da ciência e tecnologia. Porto Alegre, Brazil: Bookman.

Empresa Brasileira de Pesquisa Agropecuária. (2015). Caminhos da safra da produção e exportação de grãos. Retrieved from https://www.embrapa.br/documents/1355154/32186845/Estudo10-caminhos+da+safrappt_web.pdf/fcd34cc8-013b-bd2f-ec59-c8b06c51a88c

Grant, R. M. (1991). The resource-based theory of competitive advantage: Implications for strategy formulation. California Management Review, 33(3), 114-135. https://doi.org/10.2307/41166664

Gregor, S. (2006). The nature of theory in information systems. MIS Quarterly, 30(3), 611-642. https://doi.org/10.2307/25148742

Gregor, S., \& Hevner, A. R. (2013). Positioning and presenting design science research for maximum impact. MIS Quarterly, 3(2), 337-355. https://doi.org/10.25300/misq/2013/37.2.01

Hevner, A. R., March, S. T., Park, J., \& Ram, S. (2004). Design science in information systems research. MIS Quarterly, 28(1), 75-105. Retrieved from https://misq.org/design-science-in-information-systemsresearch.html?SID=6u4ca08juv6t5nnqln5cbf9d55

Instituto Brasileiro de Geografia e Estatística. (2006). Censo agropecuário. Retrieved September 02, 2016, from https://biblioteca.ibge.gov.br/index.php/biblioteca-catalogo?view=detalhes\&id=750

Johnson, M. W., Christensen, C. M., \& Kagermann, H. (2008). Reinventing your business model. Harvard Business Review, 86(12), 57-68. Retrieved from https://hbr.org/2008/12/reinventing-your-business-model

Klang, D., Wallnofer, M., \& Hacklin, F. (2010, June). The anatomy of the business model: A syntactical review and research agenda. Proceedings of the Summer Conference 2010 on Opening Up Innovation, London, England.

Kuechler, W., \& Vaishnavi, V. (2012). A framework for theory development in design science research. Journal of the Association for Information Systems, 13(6), 395-423. https://doi.org/10.17705/1jais.00300

Lacerda, D. P., Dresch, A., Proença, A., \& Antunes, J. A. Junior. (2013). Design science research: Método de pesquisa para a engenharia de produção. Gestão Ė Produção, 20(4), 741-761. https://doi.org/10.1590/s0104$530 \times 2013005000014$

Lei n. 5.709, de 7 de outubro de 1971. (1971). Regula a aquisição de imóvel rural por estrangeiro residente no país ou pessoa jurídica estrangeira autorizada a funcionar no Brasil, e dá outras providências. Retrieved from http://www.planalto.gov.br/ccivil_03/LEIS/L5709.htm

Lei n. 12.651, de 25 de maio de 2012. (2012). Dispõe sobre a proteção da vegetação nativa; altera as Leis $n^{\circ}$ s 6.938 , de 31 de agosto de 1981, 9.393, de 19 de dezembro de 1996, e 11.428, de 22 de dezembro de 2006; revoga as Leis $\mathrm{n}^{\circ} \mathrm{s}$ 4.771, de 15 de setembro de 1965, e 7.754, de 14 de abril de 1989, e a Medida Provisória n 2.166-67, de 24

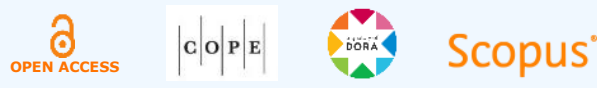


de agosto de 2001; e dá outras providências. Retrieved from http://www.planalto.gov.br/ccivil_03/_Ato2011. 2014/2012/Lei/L12651.htm

Long, T. B., Blok, V., \& Poldner, K. (2017). Business models for maximizing the diffusion of technological innovations for climate-smart agriculture. International Food and Agribusiness Management Review, 20(1), 5-23. https://doi.org/10.22434/ifamr2016.0081

Lourenzani, W. L., Souza, F. H. M., \& Bànkuti, F. I. (2003). Gestão da empresa rural - uma abordagem sistêmica. Proceedings of International Conference on Agri-Food Chain / Networks Economics and Management, Ribeirão Preto, SP, Brazil, 4.

Magretta, J. (2002). Why business models matter. Harvard Business Review, 80(5), 86-92. Retrieved from https://hbr.org/2002/05/why-business-models-matter

Mansfield, G. M., \& Fourie, L. C. H. (2004). Strategy and business models - strange bedfellows? A case for convergence and its evolution into strategic architecture. South African Journal of Business Management, $35(1), 35$ 44. https://doi.org/10.4102/sajbm.v35i1.650

McCown, R. L., Brennan, L. E., \& Parton, K. A. (2006). Learning from the historical failure of farm management models to aid management practice. Part 1. The rise and demise of theoretical models of farmeconomics. Australian Journal of Agricultural Research, 57(2), 143-156. https://doi.org/10.1071/ar05051

Ministério da Economia. (2016). Relação anual de informações sociais (RAIS). Retrieved July, 2017 from $\mathrm{ftp}: / / \mathrm{ftp} . \mathrm{mtps} . g o v \cdot b r / p d e t / m i c r o d a d o s / R A I S / 2016 /$

Morris, M., Schindehutte, M., \& Allen, J. (2005). The entrepreneur's business model: Toward a unified perspective. Journal of Business Research, 58(6), 726-735. https://doi.org/10.1016/j.jbusres.2003.11.001

Nantes, J. F. D. (1997). Gerenciamento da empresa rural. In M. O. Batalha (Coord.), Gestão agroindustrial (pp. 489. 514). São Paulo, Brazil: Editora Atlas.

Nantes, J. F. D., \& Scarpelli, M. (2001). Gestão da produção rural no agronegócio. In M. O. Batalha (Coord.), Gestão agroindustrial (2a. ed., pp. 556-584). São Paulo, Brazil: Editora Atlas.

Nielsen, C., \& Lund, M. (2012). Business model: Networking, innovating and globalizing. Copenhagen, Denmark: Ventus Publishing, Bookboon.com.

Olson, K. D. (2004). Farm management: Principles and strategies. Ames, IA: Iowa State Press.

Osterwalder, A. (2004). The business model ontology: A proposition in a design science approach (Doctoral dissertation). Ecole des Hautes Etudes Commerciales, Université de Lausanne, Lausanne, Switzerland.

Osterwalder, A., \& Pigneur, Y. (2009). Business model generation. Amsterdam, Netherlands: Modderman Drukwerk.

Osterwalder, A., \& Pigneur, Y. (2010). Business model generation. New Jersey, NJ: John Wiley and Sons.

Osterwalder, A., Pigneur, Y., \& Tucci, C. L. (2005). Clarifying business models: Origins, present, and the future of the concept. Communications of the Association for Information Systems, 16, 1-25. https://doi.org/10.17705/1cais.01601

Penrose, E. (1959). The theory of the growth of the firm. Oxford, UK: Oxford University Press.

Poláková, J., Koláčková, G., \& Tichá, I. (2015). Business model for Czech agribusiness. Scientia Agriculturae Bohemica, 46(3), 128-136. https://doi.org/10.1515/sab-2015-0027

Pölling, B., Mergenthaler, M., \& Lorleberg, W. (2016). Professional urban agriculture and its characteristic business models in Metropolis Ruhr, Germany. Land Use Policy, 58, 366-379. https://doi.org/10.1016/j.landusepol.2016.05.036

Santos, G. F. Z., Koerich, G. V., \& Alperstedt, G. D. (2018). A contribuição da design research para a resolução de problemas complexos na administração pública. Revista de Administração Pública, 52(5), 956-970. http://dx.doi.org/10.1590/0034-761220170014

Saunders, C., Kaye-Blake, W., Hayes, P., \& Shadbolt, N. (2007, June). Business models and performance indicators for agribusinesses. Retrieved from https://hdl.handle.net/10182/3647

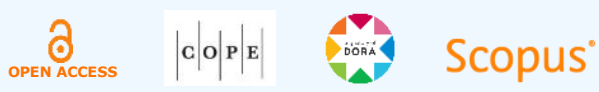


Seddon, P. B., Lewis, G. P., Freeman, P., \& Hanks, G. (2004). The case for viewing business models as abstractions of strategy. Communication of the Association for information Systems, 13(1), 427-442. https://doi.org/10.17705/1cais.01325

Teece, D. J. (2010). Business models, business strategy and innovation. Long Range Planning, 43(2-3), 172-194. https://doi.org/10.1016/j.lrp.2009.07.003

Tell, J., Hoveskog, M., Ulvenblad, P., Ulvenblad, P. O., Barth, H., \& Stahl, J. (2016). Business model innovation in the agri-food sector: A literature review. British Food Journal, 118(6), 1462-1476. https://doi.org/10.1108/bfj-082015-0293

Timmers, P. (1998). Business models for electronic markets. Joumal of Electronic Markets, 8(2), 3-8. https://doi.org/10.1080/10196789800000016

United State Department of Agriculture. (2017, July 12). World agricultural supply and demand estimates [WASDE-567]. Retrieved July, 2017, from https://downloads.usda.library.cornell.edu/usdaesmis/files/3t945q76s/9g54xh96x/bn999722v/wasde-07-12-2017.pdf

Vodovoz, E. (2015). As mudanças na tecnologia da informação e a criação de valor no modelo de negócio (Dissertação de mestrado em Administração de Empresas). Universidade Federal do Paraná, Curitiba, PR, Brazil.

Vorley, B., Lundy, M., \& MacGregor, J. (2009). Business models that are inclusive of small farmers. In C. A. da Silva, D. Baker, A. W. Shepherd, C. Jenane, \& S. Miranda-da-Cruz (Eds.), Agro-industries for development (pp. $186-$ 222). http://dx.doi.org/10.1079/9781845935764.0186

Wernerfelt, B. (1984). A resource-based view of the firm. Strategic Management Journal, 5(2), 171-180. https://doi.org/10.1002/smj.4250050207

Zott, C., \& Amit, R. (2009). Business model design: An activity system perspective. Long Range Planning, 43(2-3), $216-$ 226. https://doi.org/10.1016/j.lrp.2009.07.004

Zott, C., Amit, R., \& Massa, L. (2011). The business model: recent developments and future research. Joumal of Management, 37(4), 1019-1042. https://doi.org/10.1177/0149206311406265

\section{Author contributions}

$1^{\text {st }}$ author: conceptualization (equal), data curation (equal), formal analysis (equal), investigation (equal), methodology (equal), writing-original draft (equal).

$2^{\text {nd }}$ author: conceptualization (equal), methodology (equal), project administration (equal), writing-original draft (equal), writing-review and editing (equal).

$3^{\text {rd }}$ author: methodology (equal), writing-review and editing (equal).

$4^{\text {th }}$ author: methodology (equal), writing-review and editing (equal).

\section{Authors}

\section{André Luiz Surdi Debastiani}

Universidade do Estado de Santa Catarina

Av. Madre Benvenuta, 2037, 88035-001, Florianópolis, SC, Brazil

andredebastiani@gmail.com

(iD) https://orcid.org/0000-0002-4081-1460

\section{Graziela Dias Alperstedt}

Universidade do Estado de Santa Catarina, Centro de Ciências da Administração e Socioeconômicas Av. Madre Benvenuta, 2037, 88035-001, Florianópolis, SC, Brazil

gradial@gmail.com

(iD) https://orcid.org/0000-0003-0144-0406

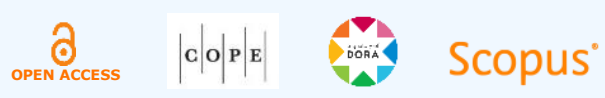




\section{Grazielli Faria Zimmer Santos}

Universidade do Estado de Santa Catarina

Av. Madre Benvenuta, 2037, 88035-001, Florianópolis, SC, Brazil

graziellizimmer1@gmail.com

(iD) https://orcid.org/0000-0002-6161-954X

\section{Graziele Ventura Koerich}

Universidade Federal de Santa Catarina

R. Eng. Agronômico Andrei Cristian Ferreira, s/n, Trindade, 88040-900, Florianópolis, SC, Brazil grazi.koerich@hotmail.com

(iD) https://orcid.org/0000-0001-7595-1714

Peer review is responsible for acknowledging an article's potential contribution to the frontiers of scholarly knowledge on business or public administration. The authors are the ultimate responsible for the consistency of the theoretical references, the accurate report of empirical data, the personal perspectives, and the use of copyrighted material. 


\section{APPENDIX}

\section{Questionnaire applied to farmers}

The following questions aim to identify the main factors that contribute to the success of an agricultural enterprise. To that end, we would like to ask you to indicate the value impact on each of the features listed below in generating competitive advantage for your business.

\begin{tabular}{|l|c|c|c|c|c|}
\hline \multirow{2}{*}{ Physical resources } & \multicolumn{3}{|c|}{ Value impact scale (1 - very low impact; - very high impact) } \\
\cline { 2 - 6 } & $\mathbf{1}$ & $\mathbf{2}$ & $\mathbf{3}$ & $\mathbf{4}$ & $\mathbf{5}$ \\
\hline Farm soil and climate conditions & & & & & \\
\hline Machine efficiency & & & & & \\
\hline Location and access to farm & & & & & \\
\hline Farm size (scale) & & & & & \\
\hline Farm infrastructure & & & & & \\
\hline
\end{tabular}

\begin{tabular}{|l|c|c|c|c|c|}
\hline \multirow{2}{*}{ Human resources } & \multicolumn{2}{|c|}{ Value impact scale (1 - very low impact; 5 - very high impact) } \\
\cline { 2 - 5 } & $\mathbf{1}$ & $\mathbf{2}$ & $\mathbf{3}$ & $\mathbf{4}$ & $\mathbf{5}$ \\
\hline Team training & & & & & \\
\hline Staff educational level & & & & & \\
\hline $\begin{array}{l}\text { Producer personal skills (creativity, initiative, } \\
\text { entrepreneurial ability) }\end{array}$ & & & & & \\
\hline $\begin{array}{l}\text { Team experience and problem-solving skills (tacit } \\
\text { knowledge) }\end{array}$ & & & & & \\
\hline Technical knowledge of agricultural activity & & & & & \\
\hline $\begin{array}{l}\text { Social capital (network of relationships with suppliers, } \\
\text { customers, associations, government, university, } \\
\text { society) }\end{array}$ & & & & & \\
\hline
\end{tabular}

\begin{tabular}{|l|c|c|c|c|c|}
\hline \multirow{2}{*}{ Organizational resources } & \multicolumn{2}{|c|}{ Value impact scale (1 - very low impact; 5 - very high impact) } \\
\cline { 2 - 5 } & $\mathbf{1}$ & $\mathbf{2}$ & $\mathbf{3}$ & $\mathbf{4}$ & $\mathbf{5}$ \\
\hline $\begin{array}{l}\text { Planning of resources used in the crop (choice of } \\
\text { crops, varieties, inputs and production systems) }\end{array}$ & & & & & \\
\hline Productivity and profitability goal setting & & & & & \\
\hline $\begin{array}{l}\text { Utilization of analysis and performance evaluation } \\
\text { mechanisms for each crop }\end{array}$ & & & & & \\
\hline $\begin{array}{l}\text { Use of information technologies (computerized } \\
\text { management systems) }\end{array}$ & & & & & \\
\hline $\begin{array}{l}\text { Definition of internal processes for each of the } \\
\text { company's purpose activities }\end{array}$ & & & & & \\
\hline Company financial management (cash flow, financing) & & & & & \\
\hline $\begin{array}{l}\text { Adoption of efficient internal communication } \\
\text { mechanisms }\end{array}$ & & & & & \\
\hline
\end{tabular}

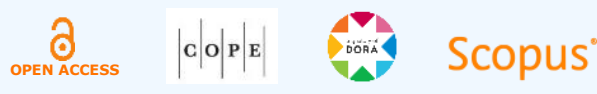


Risk management (production, market, financial, personnel, knowledge risks)

\begin{tabular}{|l|c|c|c|c|c|}
\hline \multirow{2}{*}{ Technological resources } & \multicolumn{2}{|c|}{ Value impact scale (1 - very low impact; - very high impact) } \\
\cline { 2 - 5 } & $\mathbf{1}$ & $\mathbf{2}$ & $\mathbf{3}$ & $\mathbf{4}$ & $\mathbf{5}$ \\
\hline Continuous investment in machinery and equipment & & & & & \\
\hline Experimenting with new products on the farm & & & & & \\
\hline Use of new technologies and production systems & & & & & \\
\hline Investment in precision agriculture & & & & & \\
\hline
\end{tabular}

\begin{tabular}{|l|c|c|c|c|c|}
\hline \multirow{2}{*}{ Financial resources } & \multicolumn{2}{|c|}{ Value impact scale (1 - very low impact; $\mathbf{5}$ - very high impact) } \\
\cline { 2 - 6 } & $\mathbf{1}$ & $\mathbf{2}$ & $\mathbf{3}$ & $\mathbf{4}$ & $\mathbf{5}$ \\
\hline Producer capitalization & & & & & \\
\hline Third-party credit access & & & & & \\
\hline Use of interest-bearing funds & & & & & \\
\hline Barter mechanism & & & & & \\
\hline
\end{tabular}

\begin{tabular}{|l|c|c|c|c|c|}
\hline \multirow{2}{*}{ Reputational resources } & \multicolumn{2}{|c|}{ Value impact scale (1 - very low impact; $\mathbf{5}$ - very high impact) } \\
\cline { 2 - 5 } & $\mathbf{1}$ & $\mathbf{2}$ & $\mathbf{3}$ & $\mathbf{4}$ & $\mathbf{5}$ \\
\hline $\begin{array}{l}\text { Good image with the chain (suppliers, banks, } \\
\text { community) }\end{array}$ & & & & & \\
\hline Strongly-recognized brand & & & & & \\
\hline Good relationship with customers and suppliers. & & & & & \\
\hline Transparency on social and environmental issues & & & & & \\
\hline
\end{tabular}

